This item was submitted to Loughborough's Research Repository by the author.

Items in Figshare are protected by copyright, with all rights reserved, unless otherwise indicated.

\title{
Determination of Pt-DNA adducts and the sub-cellular distribution of Pt in human cancer cell lines and the leukocytes of cancer patients, following mono- or combination treatments, by inductively-coupled plasma mass spectrometry
}

\section{PLEASE CITE THE PUBLISHED VERSION}

http://dx.doi.org/10.1016/j.ijms.2010.11.012

\section{PUBLISHER}

(c) Elsevier

\section{VERSION}

AM (Accepted Manuscript)

\section{PUBLISHER STATEMENT}

This work is made available according to the conditions of the Creative Commons Attribution-NonCommercialNoDerivatives 4.0 International (CC BY-NC-ND 4.0) licence. Full details of this licence are available at: https://creativecommons.org/licenses/by-nc-nd/4.0/

\section{LICENCE}

CC BY-NC-ND 4.0

\section{REPOSITORY RECORD}

Zayed, Aref, Tamer Shoeib, Sarah E. Taylor, George D.D. Jones, Anne L. Thomas, Joanna P. Wood, Helen J. Reid, and Barry L. Sharp. 2019. "Determination of Pt-dna Adducts and the Sub-cellular Distribution of Pt in Human Cancer Cell Lines and the Leukocytes of Cancer Patients, Following Mono- or Combination Treatments, by Inductively-coupled Plasma Mass Spectrometry". figshare. https://hdl.handle.net/2134/16066. 


\section{Determination of Pt-DNA adducts and the sub-cellular distribution of Pt in human}

cancer cell lines and the leukocytes of cancer patients, following mono- or combination treatments, by inductively-coupled plasma mass spectrometry.

Aref Zayed ${ }^{1}$, Tamer Shoeib ${ }^{1,2}$, Sarah E. Taylor ${ }^{1}$, George D. Jones ${ }^{3}$, Anne L. Thomas ${ }^{4}$, Joanna P. Wood ${ }^{4}$, Helen J. Reid ${ }^{1}$, Barry L. Sharp ${ }^{1 *}$

1. Centre for Analytical Science, Department of Chemistry, Loughborough University, Loughborough, Leicestershire LE11 3TU, UK.

2. Department of Chemistry, British University in Egypt, El Sherouk, Cairo 11837, Egypt.

3. Department of Cancer Studies and Molecular Medicine, University of Leicester, University Road, Leicester LE1 7RH, UK.

4. Department of Cancer Studies and Molecular Medicine, University Hospitals of Leicester NHS Trust, Osborne Building, Royal Infirmary, Leicester, LE1 5WW, UK.

\section{* B.L.Sharp@,lboro.ac.uk}

\section{Abstract}

This paper describes methodologies, based on sector field inductively-coupled plasma mass spectrometry (SF-ICP-MS), and their application in the holistic study of the fate of 
Pt in human cell populations following treatment with cis- or oxaliplatin and combination treatments. Pt-DNA adduct formation data at several time points has been determined in the leukocytes from patients undergoing Pt-based chemotherapy demonstrating significant inter-patient variability and excellent reproducibility of the assay. The sensitivity of the technique enabled quantitation of as little as $0.2 \mathrm{Pt}$ adducts per $10^{6}$ nucleotides using $10 \mu \mathrm{g}$ of patient DNA. Further, the first ever reported in vivo subcellular Pt fractionation data on a patient sample is presented indicating the feasibility of applying the methods presented here in a clinical environment. For in vitro studies, three cell models were used: A549 human lung adenocarcinoma epithelial cells were exposed to $50 \mu \mathrm{M}$ cisplatin for 1 hour; HCA7 human colorectal cancer cells were treated with either FOLFOX (200 $\mu \mathrm{M}$ 5-fluorouracil, $200 \mu \mathrm{M}$ folinic acid and $50 \mu \mathrm{M}$ oxaliplatin $)$ or $50 \mu \mathrm{M}$ oxaliplatin; and HT29 human colorectal cancer cells were treated with $50 \mu \mathrm{M}$ oxaliplatin in combination with $20 \mu \mathrm{M}$ methaneseleninic acid, $\mathrm{CH}_{3} \mathrm{SeO}_{2} \mathrm{H}$ (MSA). The cells were harvested and either the DNA extracted and/or a commercially available kit used to fractionate the treated cells into four sub-cellular compartments. Each of the subcellular fractions and extracted DNA were digested separately, evaporated to dryness and reconstituted in $2 \%$ nitric acid for analysis by SF-ICP-MS. The sub-cellular Pt distribution for cisplatin treated A549 cells was shown to be as follows: $\sim 70 \%$ localized in the cytosol, $\sim 17 \%$ in the membrane and membrane localized fraction, $\sim 9 \%$ in the nuclear fraction and $\sim 4 \%$ in the cytoskeletal fraction. Both FOLFOX and oxaliplatin treated HCA7 cells showed comparable sub-cellular Pt distributions, and Pt-DNA adduct formation was similar for the oxaliplatin and FOLFOX treatments with adduct yields of 5.6 and 5.5 adducts per $10^{6}$ nucleotides respectively. It was found that the combination of 
oxaliplatin with $20 \mu \mathrm{M}$ MSA did not change the distribution of Pt or significantly alter its accumulation in the cytosol of the HT29 cells. Mass balance experiments showed a $>99$ $\%$ recovery of the total $\mathrm{Pt}$ in the sub-cellular fractions. These experiments are the first to provide such a detailed quantitation of Pt-drug partitioning and they show that the $\mathrm{Pt}$ broadly follows the total protein content of the individual compartments with the majority being scavenged in the cytosol compartment.

\section{Key Words: Cisplatin, Oxaliplatin, FOLFOX, Pt-DNA adducts, Sub-cellular Fractionation, ICP-MS, Mass Balance, Selenium, Clinical samples}

\section{Introduction}

Rosenberg first reported the chemotherapeutic action of diamminedichloroplatinum(II), commonly known as cisplatin, in 1969 and since then it has arguably become the most prominent metal complex in medicine. It is by far the most widely employed anti-cancer agent in the treatment of head, neck, lung, ovarian, testicular and cervical cancer [1] and its great success is perhaps best exemplified in that, with early diagnosis, it has been shown to be a near total cure for testicular cancer [2]. Despite the success, there are concerns regarding its side effects such as neurotoxicity and damage to the kidneys [3-6]. The acquired resistance of some cancer cells to the drug following initial treatment and the inability to confer lasting remissions have also been recognised as major drawbacks

of cisplatin chemotherapy [7-10]. As a result, the identification and characterisation of other metal complexes for cancer treatment is ongoing. 
Oxaliplatin, a complex consisting of a platinum centre bound to two bidentate ligands; oxalate and a diaminocyclohexane (dach), is a third-generation anti-tumour agent that is used for treating colorectal cancer [11-13] and has been successful in treating cell lines and tumours that have developed resistance to cisplatin and other platinum based anticancer drugs [12-14]. Oxaliplatin also produces side effects such as haematological suppression and neuropathy [15], although it has been suggested that these effects are less pronounced relative to cisplatin $[13,14,16]$. At the molecular level both Pt-drugs are believed to kill cancer cells by binding to DNA, their ultimate pharmacological target [17-19]. Not surprisingly therefore, many experimental and theoretical studies have focused on Pt attachment to DNA [20-23]. Oxaliplatin undergoes ligand exchange in physiological conditions where the oxalate ligand is replaced by two chloride ligands to form $\left[\mathrm{Pt}(\mathrm{dach})(\mathrm{Cl})_{2}\right][24]$. It is widely accepted that upon the $\left[\mathrm{Pt}(\mathrm{dach})(\mathrm{Cl})_{2}\right]$ complex, or cisplatin, entering a cell, the semi-labile chlorides in either species are replaced by water ligands $[25,26]$. This does not readily occur in the blood stream, where the drugs are introduced intravenously, due to the high concentration of free circulating chloride ions $[25,26]$. It is by undergoing this partial hydrolysis in the cell that these drugs are activated forming primarily cis- $\left[\mathrm{PtCl}\left(\mathrm{H}_{2} \mathrm{O}\right)\left(\mathrm{NH}_{3}\right)_{2}\right]^{+}$and cis- $\left[\mathrm{Pt}\left(\mathrm{H}_{2} \mathrm{O}\right)_{2}\left(\mathrm{NH}_{3}\right)_{2}\right]^{2+}$ in the case of cisplatin and $\left[\mathrm{Pt}(\mathrm{dach})\left(\mathrm{H}_{2} \mathrm{O}\right)_{2}\right]^{2+}$ in the case of oxaliplatin [12, 27, 28]. After penetrating the nucleus of the cell, the central Pt metal in these ions can undergo further ligand substitution reactions with DNA producing several mono-dentate adducts, as well as many intra- and inter-strand cross links, between the N7 atoms of the purine bases. The intra-strand DNA complex, where Pt bridges adjacent guanine bases, is by far the most dominant DNA adduct with either cisplatin or oxaliplatin comprising $\sim 65 \%$ of the 
total [29-32]. The resulting distortion of the DNA structure signals cell cycle arrest, allowing for repair and, if the damage levels are high enough, subsequent apoptosis [7, 19]. Intracellular Pt content is considered to play a significant role in cytotoxicity and resistance. Several studies have investigated the accumulation of cisplatin in various cancer cell types and have examined the cellular uptake of the drug as a function of exposure time [23, 33-37]. Decreased intracellular Pt concentration due to increased efflux or decreased drug uptake was also shown to cause cisplatin resistance [7, 38-42]. After entering the blood stream cisplatin or oxaliplatin can react with molecules containing strong electron donor groups (e.g. thiols, carbonyl oxygens and amino nitrogens) such as human serum albumin, one of the most abundant proteins in blood plasma [43-48]. These reactions partially inactivate the drugs and reduce their subcellular uptake. In order to reduce such interactions and to improve the cellular uptake, recent studies have focused on modifying the structure of the drugs or combining them with other molecules such as bafilomycin and methyl- $\beta$-cyclodextrin to improve their permeability through cell membranes [23, 34-37]. Inside the cell, a plethora of ligands other than DNA are available to compete for the platinum, it is thus not surprising that only a very small fraction of either intracellular cisplatin or oxaliplatin binds to their pharmacological target [49]. The isolation and quantification of these scarce Pt-DNA complexes has been the subject of many recent reports $[19,22,23,36]$. Non-DNA interactions not only account for the majority of the intra-cellular adducts formed by the Pt-drugs, thus reducing their efficacy, but there is also strong evidence suggesting that such adducts are responsible for induced resistance in cancer cells [50-52]. Key among these cellular adducts are $\mathrm{Pt}$ complexes with the cytoplasmic ligand $\gamma$ - 
glutamylcysteinylglycine (glutathione or GSH) [53]. The levels of GSH have been reported to be elevated in cisplatin resistant tumour cells [54]. It is therefore believed that GSH complexes with cisplatin are not only a major cellular sink of the drug, causing its inactivation by forming stable covalent adducts [53, 55], but also prevent cisplatin from binding to DNA. Recent studies discovered a clear positive correlation between the resistance to cisplatin and elevated cellular levels of GSH in several ovarian cancer cells [55]. The extent of Pt-GSH binding in cisplatin has been reported to account for approximately $60 \%$ of its intracellular concentration [53], while a more recent report reduced this dramatic figure suggesting that it does not exceed $20 \%$ [28].

FOLFOX is a common combination chemotherapy used for treatment of patients with colorectal cancer and is considered one of the most effective treatments for metastatic colorectal cancer. Oxaliplatin has been shown to improve the efficacy of the 5-FU and folinic acid combination [56], however the synergistic effect between these drugs is not well understood. While it is widely accepted that Pt-based drugs, such as oxaliplatin, produce their pharmacological action by forming various types of adducts with the DNA (Pt-DNA adducts), the effect of 5-FU and folinic acid on the sub-cellular distribution of oxaliplatin in the cell has not been investigated. Other combination treatments include selenium, an essential trace element in the human body, and a common supplement taken during chemotherapy [57] which has recently been shown to have some anti-cancer properties. [58] Methyl selenol $\left(\mathrm{CH}_{3} \mathrm{SeH}\right)$ has been suggested to be a highly important metabolite involved in selenium anti cancer action [59]. Moreover, it has been shown that selenium supplements can help to reduce certain toxicities such as leukopenia and 
nephrotoxicity related to platinum-based chemotherapy [60]. However, the interaction between selenium and Pt-based drugs is still not well studied.

To date only very few reports have focused on the sub-cellular fractionation of $\mathrm{Pt}$ complexes within a cell $[22,28,61-64]$. Out of these, even fewer examined the subcellular fractionation post uptake by cancer cells $[28,62,64]$ while to the best of our knowledge none was conducted on patient samples in clinical studies. In all previous studies, the sub-cellular fractions examined were obtained at the cost of destroying, and thus losing all information pertaining to other sub-cellular components, thus no holistic picture has ever been obtained.

Gibson et al. $[28,65]$ noted that there is a lack of methodologies that are able to provide information on metallodrugs in cell models at biologically significant concentrations. However, using the high sensitivity and accurate, precise and fast quantitation provided by inductively coupled plasma mass spectrometry (ICP-MS), some progress has been made. Thus Pt has been determined in a variety of clinical samples [66] and ICP-MS has been used specifically for the determination of Pt in samples from patients following Ptbased drug chemotherapy.[67-70] Nevertheless, the determination of Pt in order to further understanding of the pharmacokinetics and pharmacodynamcis of Pt-based chemotherapy remains a challenge due to the very low Pt concentrations and often limited sample amounts.

At the point of care, clinicians currently have no prior knowledge of individual patient pharmaco-dynamic or pharmaco-genetic response and therefore patients receive a standardized dose based on body surface area and kidney function. It has been estimated 
that as a result, approximately $40 \%$ of patients [71] receive inappropriate doses. This work is ultimately aimed at meeting this unmet need in oncology, to personalize doses in Pt-based drug chemotherapy.

Using the exquisite sensitivity, species independent response and linearity of state-of-theart sector field, inductively coupled plasma mass spectrometry (SF-ICP-MS), we present patient data on Pt-DNA adduct formation, individual patient variability in adduct yield, the persistence of those adducts over extended treatment cycles and evidence of their repair. Further (as detailed below), we demonstrate a methodology by which a holistic picture of drug partitioning in the leukocytes of patients undergoing chemotherapy was obtained.

Further in vitro studies employed various cell models to provide data on drug partitioning into the four major cellular compartments: a) cytosolic, b) membrane and membranelocalized, c) soluble nucleic and DNA-associated nuclear and d) cytoskeletal fractions [72]; the effect of the commonly used FOLFOX (200 $\mu \mathrm{M}$ 5-fluorouracil, $200 \mu \mathrm{M}$ folinic acid and $50 \mu \mathrm{M}$ oxaliplatin) cocktail on the partitioning of oxaliplatin and adduct formation; and the effect of selenium supplementation on oxaliplatin partitioning and adduct formation. All proteins, with the exception of those in the cytoskeletal fraction, were obtained in their native state to prevent any disturbance to the Pt-protein complexes prior to analysis. The data are not statistically powered as for a clinical trial, but are presented as proof of concept that the methodology can produce data hitherto unavailable by any other means.

\section{Experimental}




\section{Materials}

All chemicals, tissue culture media and reagents used were purchased from Sigma (Poole, UK), unless otherwise stated. $\mathrm{HNO}_{3}(70 \%)$ and $\mathrm{H}_{2} \mathrm{O}_{2}(30 \%)$ were purchased from Romil Ltd. (Cambridge, UK). Cisplatin (CAS registry number: 15663-27-1) was obtained from Teva UK. Oxaliplatin was obtained from Sanofi-Synthelabo Limited (Guildford, UK). Folinic acid (FA) and 5-Fluoro Uracil (5-FU) were obtained from Medac UK. ProteoExtract ${ }^{\circledR}$ sub-cellular proteome extraction kit for mammalian cells was obtained from Merck KGaA (UK). QIAGEN Blood \& Cell Culture DNA Midi Kit was purchased from Qiagen (Crawley, UK).

\section{In vivo clinical Pt-DNA adducts determination:}

\section{Collection of blood samples from patients}

Ethical approval for the study was granted by the Leicestershire and Rutland Research Ethics Committee (no. 6106). After obtaining informed consent, $10-15 \mathrm{ml}$ blood samples were collected from twenty eight patients undergoing treatment with different platinum based combination chemotherapy at three time points and at different treatment cycles. The patients were treated with FOLFOX (5-fluorouracil, folinic acid and oxaliplatin), EOX (epirubicin, oxaliplatin and capecitabine), Oxali/Cape (oxaliplatin and capecitabine), ECX (epirubicin, cisplatin and capecitabine), or ECF (epirubicin, fluorouracil and cisplatin) combination chemotherapy. The notional Pt drug dose for each of these regimens were $85 \mathrm{mg} / \mathrm{m}^{2}$ every 2 weeks, 12 cycles, for oxaliplatin in FOLFOX combination, $130 \mathrm{mg} / \mathrm{m}^{2}$ every 3 weeks, 6 cycles, for oxaliplatin in EOX and Oxali/Cape combinations, and $50 \mathrm{mg} / \mathrm{m}^{2}$ every 3 weeks, 6 cycles, for cisplatin in ECX and ECF combinations. However, not all patients received the same dose at each cycle as the 
starting dose had to be reduced (typicall by $20 \%$ ) in some cases due to drug toxicity. The sampling time points, chosen for patient convenience, were: immediately prior to drug administration, and one hour and twenty four hours after drug administration. Blood was taken in vials containing sufficient potassium EDTA to achieve a concentration of 1.2 - 2 mg EDTA/ml blood after collection (SARSTEDT, Germany). Samples were kept at room temperature and the leukocytes were isolated as quickly as possible.

\section{Leukocyte isolation}

Leukocytes were isolated using Ficoll-Paque PLUS (GE Healthcare, UK). The blood was diluted with an equal volume of RPMI 1640 media (Sigma-Aldrich, UK) and then $10 \mathrm{ml}$ of the blood/RMPI mixture was carefully layered on top of $12 \mathrm{ml}$ Ficoll-paque PLUS and centrifuged at $1700 \mathrm{rpm}$ for 30 minutes at room temperature. The inter-phase layer was collected with a Pasteur pipette and was washed twice in RPMI 1640 media. Cells were frozen and stored at $-80{ }^{\circ} \mathrm{C}$ in RPMI media containing $20 \%$ foetal calf serum (FCS) and $10 \%$ DMSO.

\section{DNA extraction from leukocytes}

DNA was extracted from isolated leukocytes using Blood \& Cell Culture DNA Kit from QIAGEN (Crawley, UK) according to the manufacturer's protocol. Briefly, the frozen leukocyte samples were thawed and washed twice with PBS. Cells were then lysed and the cell nuclei were collected as pellets following centrifugation. Protein in samples was digested using Protease enzyme and DNA was extracted from samples using DEAE ion exchange cartridges. The final DNA samples were dissolved in water before determining the DNA content by measuring the UV absorbance at $260 \mathrm{~nm}$ wavelength. Samples were stored at $-20^{\circ} \mathrm{C}$ for subsequent SF-ICP-MS analysis. 
A549 human lung adenocarcinoma epithelial cell line, a non-small cell lung cancer (NSCLC) cell line, HT29 and HCA7 human colorectal cancer cell lines used in this study were purchased from the American Type Culture Collection (ATCC, USA). A549 cells have been reported to be resistant to cisplatin and therefore represent a suitable model for examining the holistic fate of the platinum [73]. RPMI 1640 media containing Lglutamine with $10 \%$ FCS were used to grow the A549 cells used in this study. HT29 and HCA7 cells were cultured in Dulbecco's modified Eagle's media supplemented with $10 \%$ FCS and $4500 \mathrm{mg} / \mathrm{L}$ glucose. All the cells were grown in an incubator at $37{ }^{\circ} \mathrm{C}$ in a $5 \%$ $\mathrm{CO}_{2}$ atmosphere. No antibiotics were added to the media. Cells were tested and confirmed as mycoplasma contamination free.

\section{Drug treatment of cells}

A549 cells were incubated with freshly prepared solutions of cisplatin in media $(50 \mu \mathrm{M})$ for 1 hour at $37^{\circ} \mathrm{C}$ before washing with PBS and collection by trypsinisation. HCA7 cells were incubated with oxaliplatin $(50 \mu \mathrm{M})$ or FOLFOX (50 $\mu \mathrm{M}$ oxaliplatin, $200 \mu \mathrm{M}$ 5-FU and $200 \mu \mathrm{M}$ FA). HCA7 cells were cultured in duplicate to study the sub-cellular fractionation of Pt as well as Pt-DNA adduct formation. HT29 cells were treated with either oxaliplatin $(50 \mu \mathrm{M})$ or oxaliplatin $(50 \mu \mathrm{M})$ in combination with methaneseleninic acid, $\mathrm{CH}_{3} \mathrm{SeO}_{2} \mathrm{H}(\mathrm{MSA})(20 \mu \mathrm{M})$. Non-drug treated control cells were also processed alongside the drug treated cells. To study Pt-DNA adduct formation, DNA was also isolated from the HCA7 cells that were treated with oxaliplatin and FOLFOX using QIAGEN Blood \& Cell Culture DNA Midi Kit. 


\section{Sub-cellular fractionation}

To obtain the sub-cellular fractions an extraction procedure with the ProteoExtract ${ }^{\circledR}$ subcellular proteome extraction kit (Merck KGaA (UK)) was performed on the harvested cell pellets described in detail elsewhere [72]. An equal volume of harvested cell pellets was used to carry out a mass balance experiment and the Pt content of the drug treated whole cell extracts was determined.

\section{Sample preparation}

The digestion method employed was originally described by Yamada et al. [74] and modified by Kerr [75]. Briefly, 0.8 volume of $70 \%$ nitric acid was added to 1 volume of each extracted DNA sample or sub-cellular fraction and heated at $70{ }^{\circ} \mathrm{C}$ for one hour followed by the addition of 0.8 volume of $30 \%$ hydrogen peroxide and heating at the same temperature for a further 4 hours. In the case of whole cell extracts, used for mass balance, $300 \mu \mathrm{l}$ each of $70 \%$ nitric acid and $30 \%$ hydrogen peroxide were used in the same digestion procedure. The resulting digest was evaporated to dryness under a gentle stream of high purity argon gas then reconstituted in $300 \mu \mathrm{lor} 1 \mathrm{ml}$, for the extracted DNA samples and sub-cellular fractions respectively, of $0.5 \mathrm{ppb}$ Eu solution, used as internal standard, in $2 \%$ nitric acid. Prior to SF-ICP-MS analysis, the whole cell extract samples were diluted by 100 fold with $2 \%$ nitric acid.

\section{Instrumental and measurement procedure}

Analyses were performed on a sector-field ICP-MS instrument (ThermoFisher Element 2 XR, Bremen, Germany). The instrument was fitted with a cyclonic spray chamber (Glass Expansions, Victoria, Australia) and a PFA nebuliser (PFA-ST Elemental Scientific, 
Omaha, USA). Typical operating parameters for the instrument are summarised in Table 1. The low resolution peak jump mode, with 13 passes per run and 3 runs per sample, was used to measure ${ }^{195} \mathrm{Pt}$ and ${ }^{153} \mathrm{Eu}$ which was used as an internal standard (see below). In the case of DNA sample analysis, ${ }^{31} \mathrm{P}$ was also measured in the medium resolution mode.

The determination of Pt by ICP-MS is potentially subject to spectral and non-spectral interferences. However, spectral interferences from metal oxide formation such as hafnium oxide is not significant in biological samples since the Hf background is lower than the Pt background [76-78]. Furthermore, metal oxide formation can be minimized by optimizing the gas flow rate and plasma ionization conditions. Hence, the conditions were optimised before each analysis for maximum sensitivity and minimum metal oxide formation. Non-spectral interferences, from the complex sample matrix, that affected the Pt signal were overcome by digesting the matrix prior to the analysis and using Eu as an internal standard.

\section{Use of Eu as an internal standard}

$\mathrm{Eu}$ was selected as a suitable internal standard for this work because it gave the best performance in improving the quantification of both $\mathrm{Pt}$ and $\mathrm{P}$ in different concentrations of the DNA sample matrix compared to 40 other elements screened and evaluated for this purpose. Eu produced the lowest \%RSD values for intensity ratios to both $\mathrm{Pt}(\mathrm{Eu}: \mathrm{Pt})$ and $\mathrm{P}(\mathrm{Eu}: \mathrm{P})$, and the lowest relative \% error in Pt quantification in varying concentrations of sample matrix.

\section{Calculation of the number of Pt-DNA adducts per number of DNA nucleotides}


The number of Pt-DNA adducts was calculated using the Pt concentrations obtained from the SF-ICP-MS data. The number of DNA nucleotides, however, could be obtained by two ways, either from the DNA concentrations determined by UV or from $\mathrm{P}$ data obtained from SF-ICP-MS. In this study, the latter method was used to determine the number of DNA nucleotides since it was found that using the $\mathrm{Pt} / \mathrm{P}$ ratio to calculate the number of Pt-DNA adducts per nucleotide was a more robust approach and gave more reproducible values. The $\mathrm{Pt} / \mathrm{P}$ was robust against matrix effects and produced very consistent data in different DNA matrix concentrations. The use of the Pt/P ratio would also have cancelled errors due to sample losses during the sample preparation in a similar way to improving quantification by using analyte/internal standard ratios. Moreover, using the $\mathrm{P}$ data to calculate the number of DNA nucleotides (each phosphorus atom corresponds to one nucleotide) is in principle more accurate than using the DNA concentrations from the UV data which requires averaging the RMM's of the four different DNA nucleotides.

\section{Results and Discussion}

Figure 1 and Figure 2 present the Pt-DNA adduct formation data obtained from twenty eight patients on various cisplatin or oxaliplatin based chemotherapies. Data are presented (whenever it was possible to obtain patient samples), at three time points and at different treatment cycles. The time points chosen for patient convenience were: immediately prior to Pt-drug administration, one hour and twenty four hours after Pt-drug administration. All patients on the first cycle of treatment either did not exhibit any PtDNA adduct formation, prior to Pt-drug administration, or such adducts (from environmental Pt) were present at levels below the instrumental limit of detection. The 
lower limit of quantitation (LLOQ) of Pt in white blood cells from the clinical blood samples was determined to be $0.2 \mathrm{Pt}$ adducts per $10^{6}$ nucleotides using $10 \mu \mathrm{g}$ of patient DNA. This figure is lower than reported values of 1.9 to 3.0 Pt-DNA adduct per $10^{6}$ nucleotides determined by the post-labelling assay [79] in white blood cells of patients after cisplatin chemotherapy. It is clear from Figure 1 and Figure 2 that the method employed here allows for the measurement of in vivo Pt-DNA adducts formed due to the administration of a variety of Pt-drugs at clinical concentrations. Excellent reproducibility was obtained, as shown in Table 2, whenever patient DNA was available in sufficient quantity to allow for duplicate measurements to be performed. The reproducibility of the results was shown for several different samples from patients on various treatment regimes, on different treatment cycles and using varying amounts of DNA, as detailed in Table 2. The excellent agreement of the Pt-adduct data from these replicate analyses illustrates the reproducibility of the DNA extraction and digestion procedures employed, in addition to the instrumental analysis. More remarkably, the sensitivity of this method allowed for the detection and quantitation of Pt-DNA adducts, prior to Pt-drug administration, in patients who had had previous chemotherapeutic cycles. The presence of these Pt-DNA adducts indicates their persistence in the DNA in patients' white blood cells for the length of time between each Pt-drug administration cycle which is typically two to three weeks. This carry over phenomenon may play a role in patients' response to chemotherapy and should be investigated further.

The variability between patients in Pt-DNA adduct formation shown in Figure 1 and Figure 2 can be attributed to numerous causes including the varying doses and combination therapies administered or the different types of cancers presented. This 
variability however, also indicates that some host-specific factors may have a role to play. The Pt-DNA adduct levels at one hour and twenty four hours after drug administration were not substantially different for most of the patients studied. Work elsewhere has shown DNA adduct formation peaking at around 6 hours after Pt-drug administration [80, 81]. Sample collection at this time point, however, was not convenient to patients in this cohort and thus it was not possible to obtain intermediate time point data. The interpatient variability in the ratio of Pt-DNA adducts at the one hour and twenty four hour time points shown in Figure 1 and Figure 2, although only small for most patients, may explain individual variability in tolerance to side effects caused by chemotherapy and increased resistance to the Pt-drug. Of particular interest is patient 7, see Figure 1, who presented with a T3N1 gastro-oesophageal adenocarcinoma and showed the highest PtDNA adduct formation among the cisplatin group. This patient experienced high levels of toxicity, however exhibited a complete pathological response upon surgical resection after chemotherapy. Alternatively, patient 24, see Figure 2, who showed the highest levels of Pt-DNA adduct formation at 1 hour among the oxaliplatin group also demonstrated the most significant reduction of Pt-DNA adducts after twenty four hours. This substantial DNA repair capacity may have been responsible for this patient's increased tolerance to side effects as compared with others in the same group.

Whilst the data presented are from a small number of patients, some qualitative observations can be drawn indicating a need for further study. Most noteworthy of these was that comparing the adduct data with clinical notes there was prima facie evidence for some patients of a positive correlation between adduct formation and toxicity. Since the majority of patients receiving Pt are receiving palliative care, toxicity is the main driver 
of clinical pathway and predictive markers for toxicity are of considerable potential clinical value. Further, in some cases, it may be that a critical concentration of Pt-DNA adducts is required to cause cell apoptosis, but that exceeding this critical concentration, without a substantial DNA repair capacity, could lead to significant toxicities. Importantly these data also provide support for the hypothesis that the nuclear DNA from healthy white blood cells can in some circumstances be a useful model for predicting drug performance in tumour tissue.

These observations in conjunction with the current hypothesis that Pt-non DNA interactions may correlate with toxicity led us to examine the sub-cellular Pt-drug partitioning in several human cell types treated in vitro with a variety of Pt-drugs. Figure 3 shows a snapshot of the Pt distribution (percentage of $\mathrm{Pt}$ ) in each of the four subcellular fractions of the different types of human cancer cells after treatment with Pt for 1 hour. Excellent reproducibility of these results was demonstrated by performing one of the sub-cellular fractionation experiments in six replicates as shown in Figure 3. The Pt sub-cellular distribution was not only internally reproducible in replicate measurements but also across different cell cultures of the same cancer cell line after incubation with the same Pt drug. The Pt sub-cellular distribution observed was also very comparable across the different cancer cell lines and the variety of Pt-drugs used in this study, as shown in Figure 3, while the Pt signals obtained for all non-drug treated control samples were below the instrumental detection limit.

Table 3 lists typical protein contents in each of the fractions obtained by the extraction procedure described here as a percent of the total proteins obtained from various human 
cells. Comparing these data with those in Figure 3 shows a strong correlation between $\mathrm{Pt}$ and protein abundance as might be expected given the variety of potential binding sites available. The cytosolic fraction contains many highly abundant proteins and therefore it is perhaps not surprising that these fractions were shown to contain the largest subcellular concentrations of Pt, accounting for about $70 \%$ of the Pt-drug incorporated into the various cancer cells. This figure is in agreement with previous fluorescence work showing $81-86 \%$ of the intracellular concentration of a platinum rhodamine- 123 complex ending up in the cytosol of a SCC-25 cell (human squamous carcinoma cell line) 24 hours after exposure [64]. Another study employing graphite furnace atomic absorption detection showed the cytosolic fractions of healthy rat kidney and liver cells to contain 62 $\%$ and $89 \%$ respectively of cisplatin $24 \mathrm{~h}$ after injection [63]. These percentages are actually significantly higher than the corresponding $30-50 \%$ protein content of the cytosol. This suggests that protein content is not the sole factor affecting sub-cellular Pt distribution. The presence of other small cytoplasmic molecules with high affinity to Ptdrugs, such as glutathione [28], as well as possible preferential Pt binding could be among the reasons for such a favourable sub-cellular Pt partitioning. It is also possible that some of the Pt-drug, upon penetration of cellular walls, remains free and unbound to biological ligands. Following the extraction procedure employed here most, if not all, of any such unbound Pt species would be collected in the cytosolic fractions.

The nuclear fractions are of special interest as they contain the DNA, the ultimate pharmacological target of the Pt-drugs. These fractions were shown to contain no more than $9 \%$ of the total Pt incorporated in any of the various Pt-drug treated cancer cells used in this study irrespective of the type of cancer cell or the kind of Pt-drug used in cell 
treatment. However, the nuclear fractions obtained here not only contained DNA but all nuclear material such as RNA, chromosomes, nucleoplasm and histones, all of which contain electron donor groups making them potential ligands for the Pt-drugs. This is reflected in data from several previous reports suggesting that Pt-DNA complexes account for about $1 \%$ of the total Pt incorporated in cells $[78,82,83]$. The partitioning assay affords opportunity to establish whether the reported synergy from combining oxaliplatin, 5-FU and folinic acid in the FOLFOX regimen could be related to changes in Pt distribution in the cell or adduct formation. The data presented in Figure 3 shows a very similar sub-cellular distribution of Pt in the HCA7 human colorectal cancer cells upon their treatment with the oxaliplatin or FOLFOX. Further, the Pt-DNA adduct formation was similar in both cases yielding 5.6 and 5.5 adducts per $10^{6}$ nucleotides respectively. While the sub-cellular distribution and Pt-DNA adduct formation data are all snapshots at an incubation time of 1 hour, such comparable results support the view that other factors such as up- and down-regulations of drug transporters and over expression of glutathione play a major role in the synergistic action of FOLFOX drug combination [84]. The partitioning assay was also applied to study the effect of Se supplementation combined with oxaliplatin. However, due to the high reactivity of methyl selenol, MSA was used in this work to generate the more reactive species in situ. Figure 4 shows the measured sub-cellular Pt distribution, averaged over six very reproducible replicate analyses, in multiple HT29 human colorectal cancer cell cultures, each after their incubation either with a combination of $20 \mu \mathrm{M}$ MSA and $50 \mu \mathrm{M}$ oxaliplatin or with only $50 \mu \mathrm{M}$ oxaliplatin for one hour. Comparison of this data, obtained with and without the addition of MSA under the same conditions, showed no 
statistical significant difference in the observed distribution of the Pt when Se was present. Selenium is a potential competitor with Pt for the available binding sites and thus could change the Pt distribution, but this was not observed in these pilot experiments.

The amount of sub-cellular Pt-drug lost due to the cell fractionation procedure employed here was investigated in order to validate the data. Equal volumes of cells, treated and untreated with Pt-drugs, were used to establish a Pt mass balance against the fractionated counterparts. These samples were not fractionated into sub-cellular components but rather subjected to harsh whole cell digestion conditions, evaporated to dryness and made up to the same volume of $2 \%$ nitric acid used for each of the fractions of the subcellular experiments. The whole cell extracts were then diluted 98.5 times in $2 \%$ nitric acid prior to analysis by ICP-MS. The Pt content of cisplatin treated whole cell extracts for example was determined to be $11.5 \mathrm{ng} / 10^{6}$ cells, see Table 4 ; this value compares well with a recent study reporting a sub-cellular Pt concentration of $10 \mathrm{ng} / 10^{6}$ cells when $\sim 3 \times 10^{6}$ A2780 cisplatin resistant cells were exposed to $50 \mu \mathrm{M}$ cisplatin for 1 hour [23]. The determined value for the cisplatin treated whole cell extracts compared very favourably with the sum of the Pt content in all four corresponding cisplatin treated subcellular fractions obtained here at $11.5 \mathrm{ng} / 10^{6}$ cells, presented in Table 4 . This yielded a Pt recovery of $>99 \%$ which was typical of all mass balance experiments performed and provides confidence in the procedure employed. Such high Pt recovery also allows for the possibility of further separation/speciation of the fractions and identification of individual proteins or families of proteins binding to $\mathrm{Pt}$.

The sub-cellular fractionation in vivo of a patient sample on cycle 9 of a FOLFOX chemotherapeutic regime was carried out to test the feasibility of the fractionation 
method employed here in a clinical environment, see Figure 5. Here there was evidence of continued drug migration into the cells over 24 hours, excepting for the cytoskeletal fraction. The results obtained clearly indicate that this method is able to detect subcellular Pt concentrations in patient samples prior to, one hour after, and twenty four hours after FOLFOX administration as is shown in Figure 5. This is the first ever reported sub-cellular fractionation and Pt determination on an in vivo clinical sample. The same trend was observed as for the in vitro studies on cancer cell lines which further supports the hypothesis that the white blood cells behave similarly to cancer cells in terms of Pt-drug partitioning.

\section{Conclusion}

Sector-field ICP-MS has made it possible to determine the number of Pt-DNA adducts formed in white blood cells of patients on a variety of different Pt-drug based chemotherapies. The detection and quantitation of Pt-DNA adducts prior to Pt-drug administration in patients who had previous chemotherapeutic cycles was also possible. Significant variability between patients in Pt-DNA adduct formation was found, which may be partially due to host-specific factors, in some cases this correlated with either efficacy, or toxicity, or both. Some inter-patient variability in the ratio of Pt-DNA adducts at one hour and twenty four hour post drug administration was shown and there was evidence to suggest that a substantial DNA repair capacity may be correlated with increased tolerance to side effects.

Combining the SF-ICP-MS methodology with a cell fractionation procedure allowed, for the first time, the determination of the entire sub-cellular Pt distribution within several human cancer cell lines following in vitro exposure to a variety of Pt-drugs. The Pt sub- 
cellular distribution was internally reproducible in replicate measurements and across different cell cultures of the same cancer cell line after incubation with the same Pt drug. The Pt sub-cellular distribution observed was also very comparable across the different cancer cell lines and the variety of Pt-drugs used in this study. The Pt sub-cellular partitioning data presented was shown to broadly follow the sub-cellular protein distribution of several typical human cells. The cystolic fractions in the Pt-drug treated cells, however, were shown to contain an elevated intracellular Pt concentration relative to the corresponding protein content. The presence of other non-protein, cytoplasmic molecules with high affinity to Pt-drugs, such as glutathione, as well as possible preferential Pt binding were suggested to be among the reasons for such a favourable subcellular Pt partitioning. The addition of selenium (in the form of $\mathrm{CH}_{3} \mathrm{SeO}_{2} \mathrm{H}$ ) during cell incubation with oxaliplatin after 1 hour did not change the distribution of Pt or significantly alter its accumulation in the cytosol. The amount of sub-cellular Pt-drug lost due to the cell fractionation procedure employed here was investigated by mass balance experiments yielding typical Pt recovery values of $>99 \%$.

The first ever in vivo sub-cellular Pt fractionation data on a patient sample was reported and shows the feasibility of applying the methods presented here in a clinical environment. Gaining a holistic picture of drug partitioning will be a valuable step towards understanding the pharmacokinetic response of individual patients to Pt-based chemotherapy both in terms of drug efficacy and the prediction of unwanted side effects. The methodology has been applied here to Pt-drugs but it can equally be applied to any metallo-drug or those containing hetero atoms such as $\mathrm{Br}$ or I. 


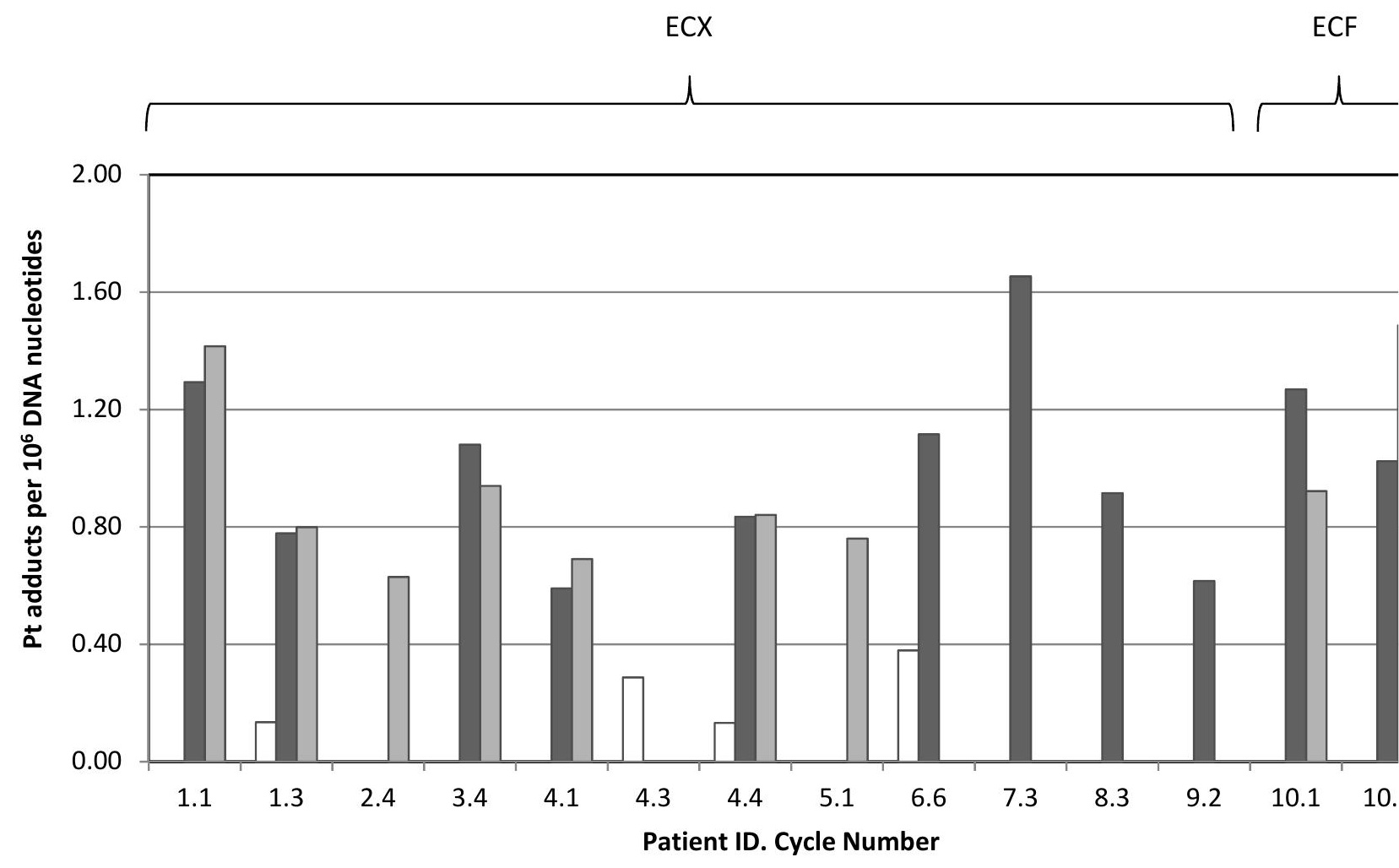

Figure 1 Pt-DNA adduct formation data obtained from ten patients on cisplatin based combination chemotherapy. Patients 1-9 were on epirubicin, cisplatin and capicitabine combination therapy (ECX). Patient 10 was on epirubicin, fluorouracil and cisplatin combination therapy (ECF). Data is presented whenever blood samples were available at three time points: immediately prior to drug administration (white bars), one hour post (dark grey) and twenty four hours post (light grey) drug administration. 


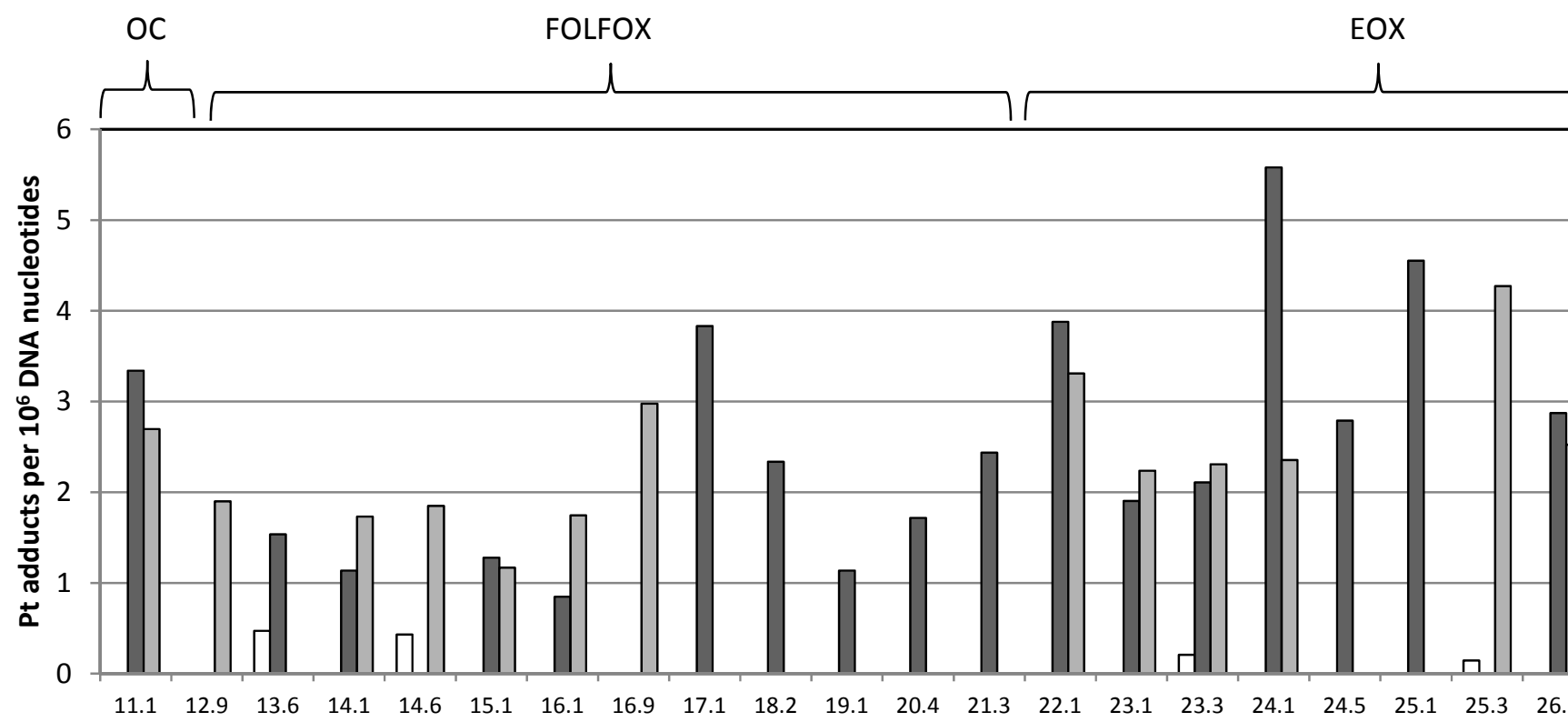

Patient ID.Cycle Number

Figure 2 Pt-DNA adduct formation data obtained from eighteen patients on oxaliplatin based combination chemotherapy. Patient 11 was on capecitabine and oxaliplatin combination (OC). Patients 12-21 were on 5-fluorouracil, folinic acid and oxaliplatin (FOLFOX) while patients 22-28 were on epirubicin, oxaliplatin and capicitabine combination chemotherapy (EOX). Data is presented whenever blood samples were available at three time points: immediately prior to drug administration (white bars), one hour post (dark grey) and twenty four hours post (light grey) drug administration. 


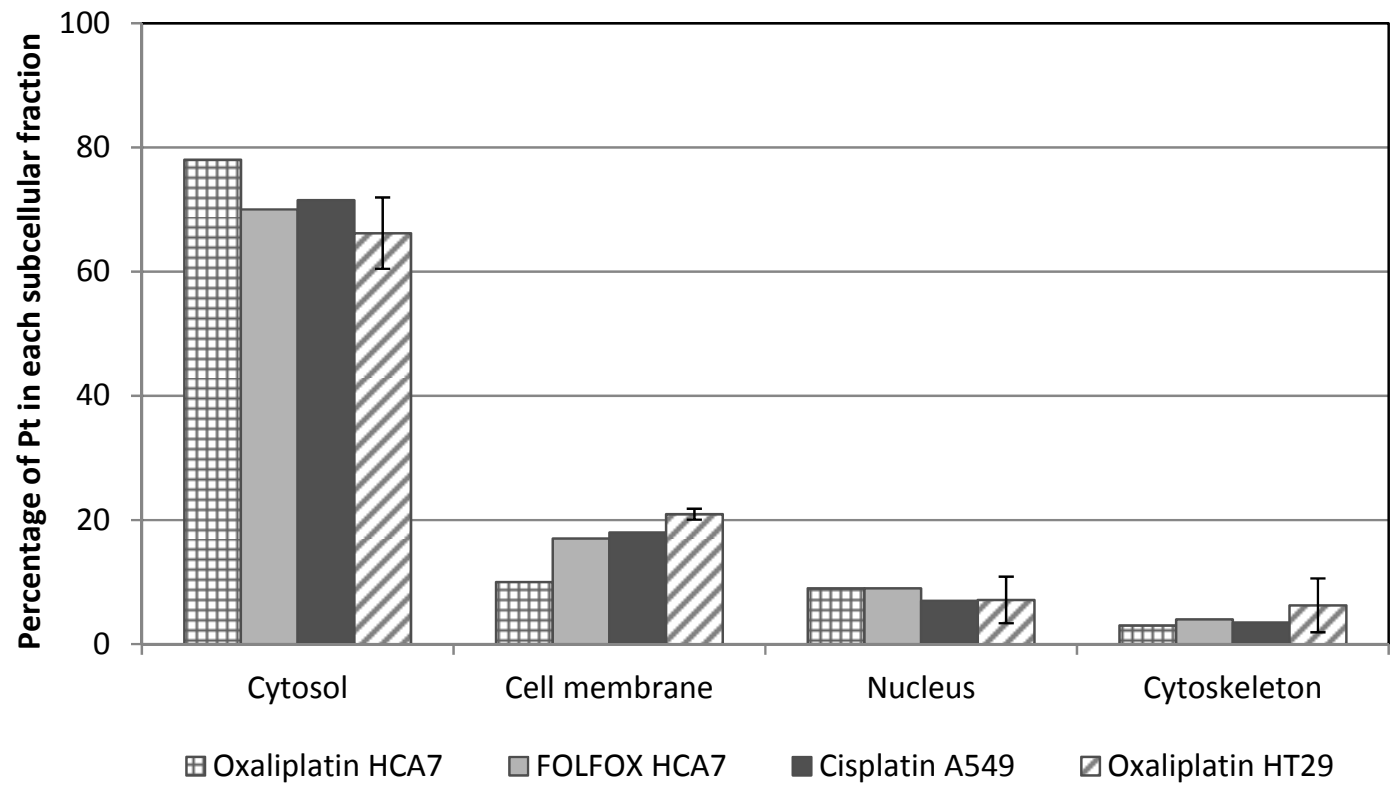

Figure 3 Relative concentrations determination in each of the four sub-cellular fractions obtained using the sub-cellular fractionation procedure after 1 hour drug treatment. Square hatched bars indicate HCA7 colorectal cancer cells incubated with $50 \mu \mathrm{M}$ oxaliplatin, light grey bars indicate HCA7 colorectal cancer cells incubated with FOFLOX (50 $\mu \mathrm{M}$ oxaliplatin, $200 \mu \mathrm{M}$ 5-fluorouracil and $200 \mu \mathrm{M}$ folinic acid), dark grey bars indicate $A 549$ lung cancer cells incubated with $50 \mu \mathrm{M}$ cisplatin, diagonal hatched bars indicate HT29 colorectal cancer cells incubated with $50 \mu \mathrm{M}$ oxaliplatin. The error bars represent t-test values at $95 \%$ confidence level for $n=6$ independently prepared samples. 


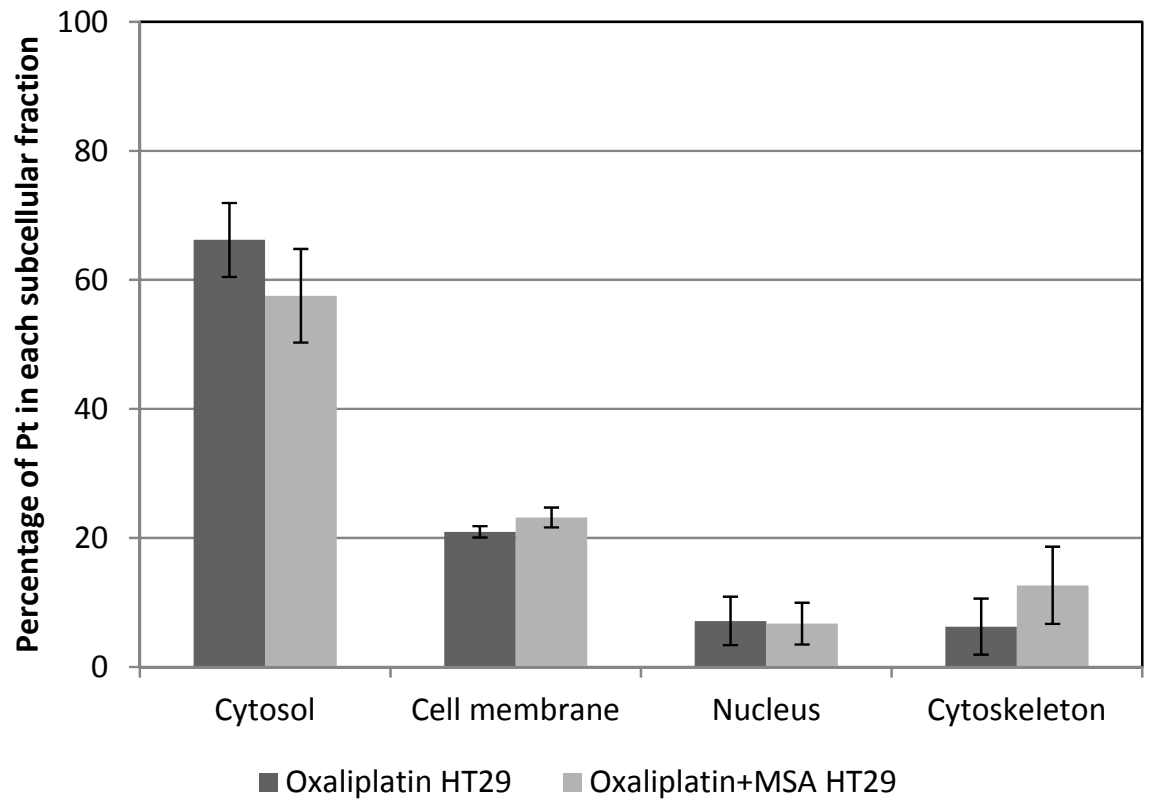

Figure 4 Relative Pt concentration determined in each of the sub-cellular fractions of the HT29 human colorectal cancer cells obtained using the sub-cellular fractionation procedure after 1 hour drug treatment. Light grey bars indicate incubation with $50 \mu \mathrm{M}$ oxaliplatin and $20 \mu \mathrm{M}$ MSA, dark grey bars indicate incubation with only $50 \mu \mathrm{M}$ oxaliplatin. The error bars represent t-test values at $95 \%$ confidence level for $n=6$ independently prepared samples. 


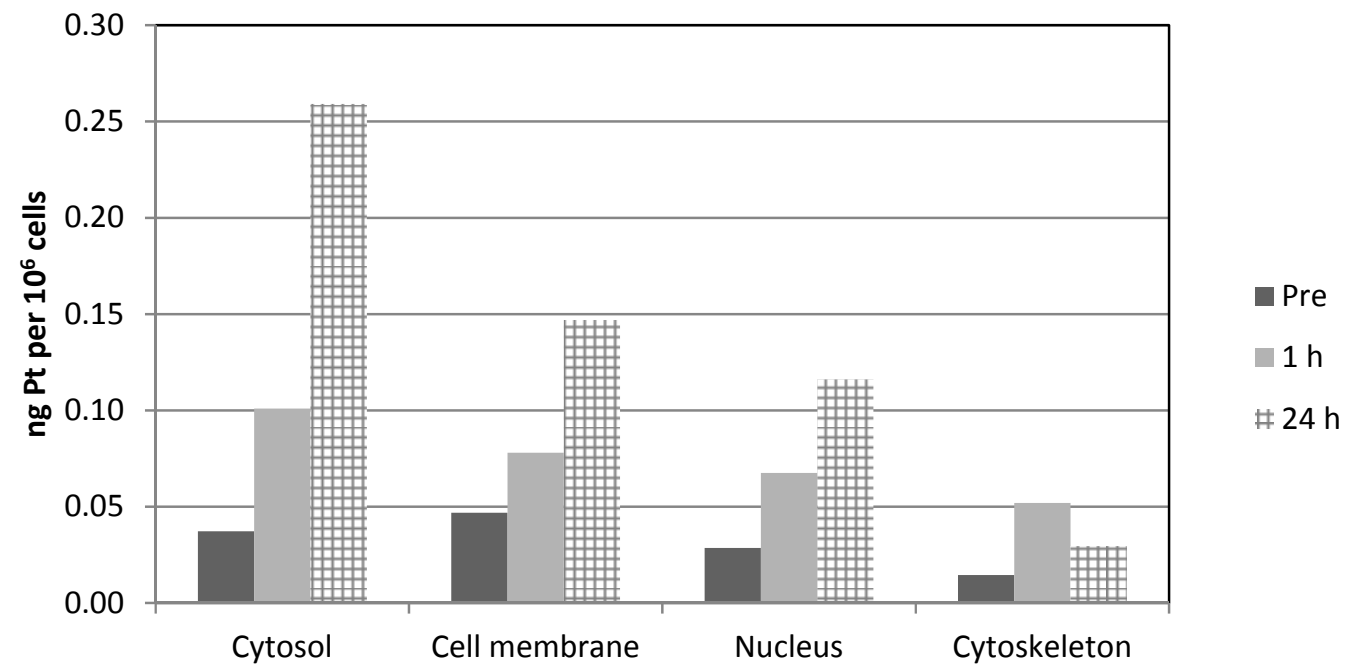

Figure 5 In vivo Pt concentration determined in each of the sub-cellular fractions of lymphocyte samples obtained from a patient on cycle 9 of FOLFOX chemotherapy. The samples were collected from the patient immediately pre-, 1 hour post- and 24 hour post-infusion of the chemotherapy. 
Table 1 Typical conditions for SF-ICP-MS

\begin{tabular}{ll}
\hline Parameter & Value \\
\hline ICP Radio Frequency (RF) power & $1250 \mathrm{~W}$ \\
Cool gas flow rate & $15.5 \mathrm{~L} \mathrm{~min}^{-1}$ \\
Auxiliary gas flow rate & $0.82 \mathrm{~L} \mathrm{~min}^{-1}$ \\
Nebuliser gas flow rate & $1.13 \mathrm{~L} \mathrm{~min}^{-1}$ \\
Sample uptake rate & $80 \mu \mathrm{L} \mathrm{min}$ \\
Sample cone & $\mathrm{Ni}$ \\
Skimmer cone & $\mathrm{Ni}$ \\
Detection mode & Triple mode \\
Resolution & Low (Pt and Eu) and Medium (P) \\
\hline
\end{tabular}


Table 2. Pt-DNA adduct formation data for clinical samples.

\begin{tabular}{|c|c|c|c|c|c|}
\hline Patient.Cycle & Time point & $\begin{array}{l}\text { Replicate } \\
\text { number }\end{array}$ & Drug & $\begin{array}{l}\text { DNA } \\
(\mu g)\end{array}$ & $\begin{array}{l}\text { Pt adduct per } 10^{6} \\
\text { nucleotides }\end{array}$ \\
\hline \multirow[t]{2}{*}{2.4} & $24 \mathrm{~h}$ & 1 & ECX & 29 & 0.63 \\
\hline & & 2 & $\mathrm{ECX}$ & 6 & 0.66 \\
\hline \multirow[t]{3}{*}{16.1} & $1 \mathrm{~h}$ & 1 & FOLFOX & 16 & 0.85 \\
\hline & & 2 & FOLFOX & 28 & 1.03 \\
\hline & & 3 & FOLFOX & 43 & 1.03 \\
\hline \multirow[t]{2}{*}{16.9} & $24 \mathrm{~h}$ & 1 & FOLFOX & 10 & 2.98 \\
\hline & & 2 & FOLFOX & 9 & 3.19 \\
\hline \multirow[t]{2}{*}{24.1} & $1 \mathrm{~h}$ & 1 & EOX & 28 & 5.58 \\
\hline & & 2 & EOX & 28 & 5.38 \\
\hline \multirow[t]{2}{*}{24.1} & $24 \mathrm{~h}$ & 1 & EOX & 7 & 2.36 \\
\hline & & 2 & EOX & 7 & 2.27 \\
\hline
\end{tabular}


Table 3 Typical protein percentages in each sub-cellular fraction obtained from various human cells following extraction using the commercial sub-cellular fractionation kit used in this study[85]

\begin{tabular}{lllll}
\hline Cell type (human) & Cytosol & Membranes & Nucleus & Cytoskeleton \\
\hline Liver carcinoma HEPG2 & $53 \%$ & $31 \%$ & $10 \%$ & $6 \%$ \\
Mamma carcinoma MCF7 & $44 \%$ & $32 \%$ & $17 \%$ & $7 \%$ \\
Osteosarcom SAOS2 & $36 \%$ & $41 \%$ & $17 \%$ & $6 \%$ \\
Epithelial carninoma A431 & $33 \%$ & $45 \%$ & $13 \%$ & $9 \%$ \\
\hline
\end{tabular}


Table 4. Pt concentration determined in each of the sub-cellular fractions and the whole cells of A549 lung cancer cells after 1 hour drug treatment.

\begin{tabular}{lr}
\hline Fraction & Pt concentration (ng Pt/10 \\
\hline Cytosol & cells) \\
Cell membranel organelle & 8.41 \\
Nucleus & 2.13 \\
Cytoskelton & 0.59 \\
Total & 0.37 \\
Whole Cells & 11.50 \\
\hline
\end{tabular}




\section{References}

[1] S.E. Sherman, S.J. Lippard, Structural aspects of platinum anticancer drug interactions with DNA, Chem. Rev. 87 (1987) 1153-1181.

[2] S. Culine, Chimiothérapie des tumeurs germinales métastatiques du testicule de bon pronostic, Oncologie 10 (2008) 446-450.

[3] L. Ta, Neurotoxicity of oxaliplatin and cisplatin for dorsal root ganglion neurons correlates with platinum-DNA binding, Neurotoxicology 27 (2006) 992-1002.

[4] P.J. O'Dwyer, J.P. Stevenson, S.W. Johnson, Clinical Status of Cisplatin, Carboplatin and Other Platinum-Based Antitumor Drugs, in: B. Lippert. (Eds.), Cisplatin: Chemistry and Biochemistry of a Leading Anticancer Drug, Wiley-VCH, 1999, 29-70.

[5] M.H. Hanigan, P. Devarajan, Cisplatin nephrotoxicity: molecular mechanisms, Cancer Ther 1 (2003) 47-61.

[6] E.R. Jamieson, S.J. Lippard, Structure, Recognition, and Processing of Cisplatin-DNA Adducts, Chem. Rev. 99 (1999) 2467-2498.

[7] M. Kartalou, J.M. Essigmann, Mechanisms of resistance to cisplatin, Mutat. Res. Fundam. Mol. Mech. Mugag 478 (2001) 23-43.

[8] V. Brabec, J. Kasparkova, Modifications of DNA by platinum complexes: Relation to resistance of tumors to platinum antitumor drugs, Drug Resist Updat 8 (2005) 131-146. 
[9] P. Heffeter, U. Jungwirth, M. Jakupec, C. Hartinger, M. Galanski, L. Elbling, M.

Micksche, B. Keppler, W. Berger, Resistance against novel anticancer metal compounds: differences and similarities, Drug Resist Updat 11 (2008) 1-16.

[10] P. Borst, S. Rottenberg, J. Jonkers, How do real tumors become resistant to cisplatin?, Cell Cycle 7 (2008) 1353-1359.

[11] L.E. Ta, L. Espeset, J. Podratz, A.J. Windebank, Neurotoxicity of oxaliplatin and cisplatin for dorsal root ganglion neurons correlates with platinum-DNA binding, NeuroToxicology, 27 (2006) 992-1002.

[12] S. Arnould, I. Hennebelle, P. Canal, R. Bugat, S. Guichard, Cellular determinants of oxaliplatin sensitivity in colon cancer cell lines, Eur. J. Cancer 39 (2003) 112-119.

[13] G.M. Almeida, T.L. Duarte, W.P. Steward, G.D.D. Jones, Detection of oxaliplatininduced DNA crosslinks in vitro and in cancer patients using the alkaline comet assay, DNA Repair, 5 (2006) 219-225.

[14] S.G. Chaney, S.L. Campbell, B. Temple, E. Bassett, Y. Wu, M. Faldu, Protein interactions with platinum-DNA adducts: from structure to function, J. Inorg. Biochem. 98 (2004) 1551-1559.

[15] R. Mandal, M.B. Sawyer, X.-. Li, Mass spectrometry study of hemoglobinoxaliplatin complexes in colorectal cancer patients and potential association with chemotherapeutic responses, Rapid Communications in Mass Spectrometry 20 (2006) $2533-2538$ 
[16] E. Raymond, S. Faivre, S. Chaney, J. Woynarowski, E. Cvitkovic, Cellular and molecular pharmacology of oxaliplatin, Mol. Cancer. Ther. 1 (2002) 227-235.

[17] S.G. Chaney, S.L. Campbell, E. Bassett, Y. Wu, Recognition and processing of cisplatin- and oxaliplatin-DNA adducts, Crit. Rev. Oncol. 53 (2005) 3-11.

[18] Y. Jung, S.J. Lippard, Direct cellular responses to platinum-induced DNA damage, Chem. Rev. 107 (2007) 1387-1407.

[19] D. Wang, S.J. Lippard, Cellular processing of platinum anticancer drugs, Nat. Rev. Drug Discov. 4 (2005) 307-320.

[20] E. Björn, Y. Nygren, T.T. Thi Nhu Nguyen, C. Ericson, M. Nöjd, P. Naredi, Determination of platinum in human subcellular microsamples by inductively coupled plasma mass spectrometry, Anal Biochem 363 (2007) 135-142.

[21] E. Volckova, L.P. Dudones, R.N. Bose, HPLC determination of binding of cisplatin to DNA in the presence of biological thiols: Implications of dominant platinum-thiol binding to its anticancer action, Pharm. Res. 19 (2002) 124-131.

[22] C. Lottner, R. Knuechel, G. Bernhardt, H. Brunner, Distribution and subcellular localization of a water-soluble hematoporphyrin-platinum(II) complex in human bladder cancer cells, Cancer Lett. 215 (2004) 167-177.

[23] P. Marqués-Gallego, G.V. Kalayda, U. Jaehde, H.d. Dulk, J. Brouwer, J. Reedijk, Cellular accumulation and DNA platination of two new platinum(II) anticancer 
compounds based on anthracene derivatives as carrier ligands, J. Inorg. Biochem. 103 (2009) 791-796.

[24] J.M. Woynarowski, W.G. Chapman, C. Napier, M.C.S. Herzig, P. Juniewicz, Sequence- and Region-Specificity of Oxaliplatin Adducts in Naked and Cellular DNA, Mol Pharmacol 54 (1998) 770-777.

[25] J. Kozelka, Molecular origin of the sequence-dependent kinetics of reactions between cisplatin derivatives and DNA, Inorganica Chimica Acta 362 (2009) 651-668.

[26] F. Arnesano, G. Natile, Mechanistic insight into the cellular uptake and processing of cisplatin 30 years after its approval by FDA, Coord. Chem. Rev. In Press, Corrected Proof (2009) 2070-2081.

[27] D.V. Deubel, Factors governing the kinetic competition of nitrogen and sulfur ligands in cisplatin binding to biological targets, J. Am. Chem. Soc. 126 (2004) 59996004.

[28] Y. Kasherman, S. Sturup, D. Gibson, Is glutathione the major cellular target of cisplatin? A study of the interactions of cisplatin with cancer cell extracts, J. Med. Chem. 52 (2009) 4319-4328.

[29] J. Reedijk, Improved understanding in platinium antitumour chemistry, Chem. Commun. (1996) 801.

[30] Z. Guo, P.J. Sadler, Metals in Medicine, Angew. Chem. Int. Ed Engl. 38 (1999) $1512-1531$ 
[31] S.M. Cohen, S.J. Lippard, Cisplatin: from DNA damage to cancer chemotherapy, Prog. Nucleic Acid Res. Mol. Biol. 67 (2001) 93-130.

[32] T.W. Hambley, Platinum binding to DNA: structural controls and consequences, J. Chem. Soc., Dalton Tans. (2001) 2711-2718.

[33] P. Ilinski, B. Lai, Z. Cai, W. Yun, D. Legnini, T. Talarico, M. Cholewa, L.K. Webster, G.B. Deacon, S. Rainone, D.R. Phillips, A.P. Stampfl, The direct mapping of the uptake of platinum anticancer agents in individual human ovarian adenocarcinoma cells using a hard X-ray microprobe, Cancer Res. 63 (2003) 1776-1779.

[34] A.E. Egger, C. Rappel, M.A. Jakupec , C.G. Hartinger, P. Heffeter, B.K. Keppler, Development of an experimental protocol for uptake studies of metal compounds in adherent tumor cells, J. Anal. At. Spectrom. 24 (2009) 51-61.

[35] R.M. Xing, Characterization and cellular uptake of platinum anticancer drugs encapsulated in apoferritin, J. Inorg. Biochem. 103 (2009) 1039-1044.

[36] D. Garmann, A. Warnecke, G.V. Kalayda, F. Kratz, U. Jaehde, Cellular accumulation and cytotoxicity of macromolecular platinum complexes in cisplatinresistant tumor cells, J. Controlled Release 131 (2008) 100-106.

[37] M. Salerno, Impact of intracellular chloride concentration on cisplatin accumulation in sensitive and resistant GLC4 cells, J. Biol. Inorg. Chem. 14 (2009) 123-132. 
[38] A. Ghezzi, M. Aceto, C. Cassino, E. Gabano, D. Osella, Uptake of antitumor platinum(II)-complexes by cancer cells, assayed by inductively coupled plasma mass spectrometry (ICP-MS), J. of Inorg. Biochem. 98 (2004) 73-78.

[39] P.A. Andrews, S.B. Howell, Cellular pharmacology of cisplatin: perspectives on mechanisms of acquired resistance, Cancer Cell 2 (1990) 35-43.

[40] J. Holford, P.J. Beale, F.E. Boxall, S.Y. Sharp, L.R. Kelland, Mechanisms of drug resistance to the platinum complex ZD0473 in ovarian cancer cell lines, Eur. J. Cancer 36 (2000) 1984-1990.

[41] Z. Chen, M. Mutoh, T. Sumizawa, T. Furukawa, M. Haraguchi, A. Tani, N. Saijo, T. Kondo, S. Akiyama, An Active Efflux System for Heavy Metals in Cisplatin-Resistant Human KB Carcinoma Cells, Exp. Cell Res. 240 (1998) 312-320.

[42] M. Mishima, G. Samimi, A. Kondo, X. Lin, S.B. Howell, The cellular pharmacology of oxaliplatin resistance, Eur. J. Cancer 38 (2002) 1405-1412.

[43] K.R. Grigoryan, M.G. Azanuryan, N.A. Bagramyan, L.G. Grvorkyan, S.A. Markaryan, Spectroscopic determination of binding between human serum albumin and a platinum(II) dimethylsulfoxide complex, J. Appl. Spectros. 75 (2008) 593-596.

[44] I. Takahashi, T. Ohnuma, S. Kavy, S. Bhardwaj, J.F. Holland, Interaction of human serum albumin with anticancer agents in vitro, Br. J. Cancer 41 (1980) 602-608. 
[45] N. Ohta, D. Chen, S. Ito, T. Futo, Effect of trans-diamminedichloroplatinum(II) on human serum albumin: conformational changes through partial disulfide bond cleavage, Int. J. Pharm. 118 (1995) 85-93.

[46] A.I. Ivanov, J. Christodoulou, J.A. Parkinson, K.J. Barnham, A. Tucker, J. Woodrow, P.J. Sadler, Cisplatin binding sites on human albumin, J. Biol. Chem. 273 (1998) 14721-14730.

[47] B.P. Espósito, R. Najjar, Interactions of antitumoral platinum-group metallodrugs with albumin, Coord. Chem. Rev. 232 (2002) 137-149.

[48] A. Warnecke, I. Fichtner, D. Garmann, U. Jaehde, F. Kratz, Synthesis and biological activity of water-soluble maleimide derivatives of the anticancer drug carboplatin designed as albumin-binding prodrugs, Bioconjug. Chem. 15 (2004) 1349-1359.

[49] V. Cepeda, M.A. Fuertes, J. Castilla, C. Alonso, C. Quevedo, J.M. Perez, Biochemical mechanisms of cisplatin cytotoxicity, Anticancer Agents Med. Chem. 7 (2007) 3-18.

[50] C.L. Litterst, V.G. Schweitzer, Covalent binding of platinum to renal protein from sensitive and resistant guinea pigs treated with cisplatin: possible role in nephrotoxicity, Res. Commun. Chem. Pathol. Pharmacol. 61 (1988) 35-48.

[51] S. Akiyama, Z.S. Chen, T. Sumizawa, T. Furukawa, Resistance to cisplatin, Anticancer Drug Des. 14 (1999) 143-151. 
[52] V. Brabec, J. Kasparkova, Molecular aspects of resistance to antitumor platinum drugs, Drug Resist Updat 5 (2002) 147-161.

[53] T. Ishikawa, F. Ali-Osman, Glutathione-associated cisdiamminedichloroplatinum(II) metabolism and ATP-dependent efflux from leukemia cells. Molecular characterization of glutathione-platinum complex and its biological significance, J. Biol. Chem. 268 (1993) 20116-20125.

[54] A.K. Godwin, A. Meister, P.J. O'Dwyer, C.S. Huang, T.C. Hamilton, M.E. Anderson, High resistance to cisplatin in human ovarian cancer cell lines is associated with marked increase of glutathione synthesis, Proceedings of the National Academy of Sciences of the United States of America 89 (1992) 3070-3074.

[55] P. Mistry, L.R. Kelland, G. Abel, S. Sidhar, K.R. Harrap, The relationships between glutathione, glutathione-S-transferase and cytotoxicity of platinum drugs and melphalan in eight human ovarian carcinoma cell lines, Br. J. Cancer 64 (1991) 215-220.

[56] T. Andre, C. Boni, L. Mounedji-Boudiaf, M. Navarro, J. Tabernero, T. Hickish, C. Topham, M. Zaninelli, P. Clingan, J. Bridgewater, I. Tabah-Fisch, A. de Gramont, Multicenter International Study of Oxaliplatin/5-Fluorouracil/Leucovorin in the Adjuvant Treatment of Colon Cancer (MOSAIC) Investigators, Oxaliplatin, fluorouracil, and leucovorin as adjuvant treatment for colon cancer N. Engl. J. Med. 350 (2004) 23432351.

[57] A. Molassiotis, P. Fernadez-Ortega, D. Pud, G. Ozden, J.A. Scott, V. Panteli, A. Margulies, M. Browall, M. Magri, S. Selvekerova, E. Madsen, L. Milovics, I. Bruyns, G. 
Gudmundsdottir, S. Hummerston, A.M. Ahmad, N. Platin, N. Kearney, E. Patiraki, Use of complementary and alternative medicine in cancer patients: a European survey, Ann. Oncol. 16 (2005) 655-663.

[58] M. Suzuki, M. Endo, F. Shinohara, S. Echigo, H. Rikiishi, Differential apoptotic response of human cancer cells to organoselenium compounds, Cancer Chemother. Pharmacol. 66 (2010) 475-484; 484.

[59] M.P. Rayman, Selenium in cancer prevention: a review of the evidence and mechanism of action, Proc. Nutr. Soc. 64 (2005) 527-542.

[60] Y. Hu, Y. Chen, Y. Zhang, M. Zhou, X. Song, B. Zhang, L. Luo, P. Xu, Y. Zhao, Y. Zhao, G. Cheng, The protective role of selenium on the toxicity of cisplatin-contained chemotherapy regimen in cancer patients, Biol. Trace Elem. Res. 56 (1997) 331-341.

[61] S.K. Mauldin, G. Gibbons, S.D. Wyrick, S.G. Chaney, Intracellular Biotransformation of Platinum Compounds with the 1,2-Diaminocyclohexane Carrier Ligand in the L1210 Cell Line, Cancer Res. 48 (1988) 5136-5144.

[62] M.E. Leibbrandt, G.H. Wolfgang, A.L. Metz, A.A. Ozobia, J.R. Haskins, Critical subcellular targets of cisplatin and related platinum analogs in rat renal proximal tubule cells, Kidney Int. 48 (1995) 761-770.

[63] R.P. Sharma, I.R. Edwards, cis-Platinum: subcellular distribution and binding to cytosolic ligands, Biochem. Pharmacol. 32 (1983) 2665-2669. 
[64] B.A. Teicher, S.A. Holden, J.L. Jacobs, M.J. Abrams, A.G. Jones, Intracellular distribution of a platinum-rhodamine 123 complex in cis-platinum sensitive and resistant human squamous carcinoma cell lines, Biochem. Pharmacol. 35 (1986) 3365-3369.

[65] D. Gibson, The mechanism of action of platinum anticancer agents - what do we really know about it? Dalton Trans. (2009) 10681.

[66] Z. Yang, X.D. Hou, B.T. Jones, Determination of platinum in clinical samples, Appl. Spectrosc. Rev. 37 (2002) 88.

[67] G.J. Veal, J. Errington, M.J. Tilby, A.D. Pearson, A.B. Foot, H. McDowell, C. Ellershaw, B. Pizer, G.M. Nowell, D.G. Pearson, A.V. Boddy, UKCCSG Pharmacology Working Group, Adaptive dosing and platinum-DNA adduct formation in children receiving high-dose carboplatin for the treatment of solid tumours Br. J. Cancer 96 (2007) $725-731$.

[68] B.W. Cooper, G.J. Veal, T. Radivoyevitch, M.J. Tilby, H.J. Meyerson, H.M. Lazarus, O.N. Koc, R.J. Creger, G. Pearson, G.M. Nowell, D. Gosky, S.T. Ingalls, C.L. Hoppel, S.L. Gerson, A phase I and pharmacodynamic study of fludarabine, carboplatin, and topotecan in patients with relapsed, refractory, or high-risk acute leukemia, Clin. Cancer Res. 10 (2004) 6830-6839.

[69] D. Pozebon, V.L. Dressler, A. Matusch, J.S. Becker, Monitoring of platinum in a single hair by laser ablation inductively coupled plasma mass spectrometry (LA-ICP-MS) after cisplatin treatment for cancer, Int. J. Mass Spectrom. 272 (2008) 57-62. 
[70] J.G. Morrison, P. White, S. McDougall, J.W. Firth, S.G. Woolfrey, M.A. Graham, D. Greenslade, Validation of a highly sensitive ICP-MS method for the determination of platinum in biofluids: application to clinical pharmacokinetic studies with oxaliplatin, J. Pharmaceut. Biomed. 24 (2000) 1-10.

[71] S. Dawood, B. Leyland-Jones, Pharmacology and pharmacogenetics of chemotherapeutic agents, Cancer Invest. 27 (2009) 482-488.

[72] A. Abdolzade-Bavil, S. Hayes, L. Goretzki, M. Kroger, J. Anders, R. Hendriks, Convenient and versatile subcellular extraction procedure, that facilitates classical protein expression profiling and functional protein analysis, Proteomics 4 (2004) 1397-1405.

[73] G.M. Almeida, T.L. Duarte, P.B. Farmer, W.P. Steward, G.D. Jones, Multiple endpoint analysis reveals cisplatin damage tolerance to be a chemoresistance mechanism in a NSCLC model: implications for predictive testing, Int. J. Cancer 122 (2008) 1810-1819.

[74] K. Yamada, N. Kato, A. Takagi, M. Koi, H. Hemmi, One-milliliter wet-digestion for inductively coupled plasma mass spectrometry (ICP-MS): determination of platinumDNA adducts in cells treated with platinum(II) complexes, Anal. Bioanal Chem. 382 (2005) 1702-1707.

[75] S. Kerr, Enhancing nucleic acid detection using inductively coupled plasma mass spectrometry, by means of metal and nano-particle labelling, PhD Thesis, Loughborough University, 2008. 
[76] I. Rodushkin, E. Engstrom, A. Stenberg, D.C. Baxter, Determination of lowabundance elements at ultra-trace levels in urine and serum by inductively coupled plasma-sector field mass spectrometry, Anal. Bioanal Chem. 380 (2004) 247-257.

[77] S. Hann, G. Koellensperger, K. Kanitsar, G. Stingeder, M. Brunner, B. Erovic, M. Muller, C. Reiter, Platinum determination by inductively coupled plasma-sector field mass spectrometry (ICP-SFMS) in different matrices relevant to human biomonitoring, Anal. Bioanal Chem. 376 (2003) 198-204.

[78] E. Brouwers, M. Tibben, H. Rosing, J. Schellens, J. Beijnen, The application of inductively coupled plasma mass spectrometry in clinical pharmacological oncology research, Mass Spectrom. Rev. 27 (2008) 67-100.

[79] M.J.P. Welters, M. Maliepaard, A.J. Jacobs-Bergmans, R.A. Baan, J.H.M. Schellens, J. Ma, W.J.F. Van der Vijgh, B.J.M. Braakhuis, A.M.J. Fichtinger-Schepman, Improved 3 2P-postlabelling assay for the quantification of the major platinum-DNA adducts, Carcinogenesis 18 (1997) 1774.

[80] G. Weber, J. Messerschmidt, A.C. Pieck, A.M. Junker, A. Wehmeier, U. Jaehde, Ultratrace voltammetric determination of DNA-bound platinum in patients after administration of oxaliplatin, Anal. Bioanal. Chem. 380 (2004) 58.

[81] E.E.M. Brouwers, M. Tibben, D. Pluim, H. Rosing, H. Boot, A. Cats, J.H.M. Schellens, J.H. Beijnen, Inductively coupled plasma mass spectrometric analysis of the total amount of platinum in DNA extracts from peripheral blood mononuclear cells and tissue from patients treated with cisplatin, Anal. Bioanal. Chem. 391 (2008) 577-585. 
[82] C.R. Centerwall, K.A. Tacka, D.J. Kerwood, J. Goodisman, B.B. Toms, R.L.

Dubowy, J.C. Dabrowiak, Modification and Uptake of a Cisplatin Carbonato Complex by Jurkat Cells, Mol Pharmacol 70 (2006) 348-355.

[83] J. Reedijk, Why Does Cisplatin Reach Guanine-N7 with Competing S-Donor Ligands Available in the Cell? Chem. Rev. 99 (1999) 2499-2510.

[84] D. Theile, S. Grebhardt, W.E. Haefeli, J. Weiss, Involvement of drug transporters in the synergistic action of FOLFOX combination chemotherapy, Biochem. Pharmacol. 78 (2009) 1366-1373.

[85] Merck Chemicals, ProteoExtract ${ }^{\circledR}$ Subcellular Proteome Extraction Kit, http://www.merck-chemicals.co.uk/life-science-research/proteoextract-subcellularproteome-extraction-kit/EMD BIO-539790/p xdCb.s1ORVMAAAEjpxp9.zLX (accessed 7/11/2010, 2010). 